\section{prestidemits corpert}

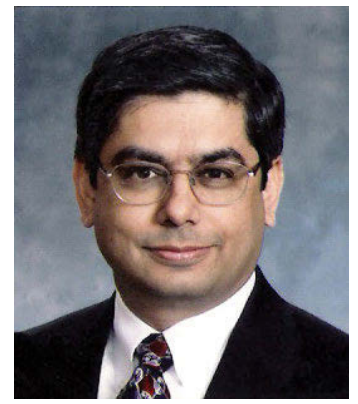

\section{Looking Forward to Serving SID}

\section{by Amal Ghosh \\ President, Society for Information Display}

I look forward to serving as the President of SID for the next 2 years. As you may know, our premier society for displays is in its 52nd year of existence and is doing well. An organization such as ours is primarily based on the hard work of many volunteers, without whom SID would not survive. To that end, I would like to thank all the SID volunteers for the countless hours of personal and professional sacrifice they have made to help SID become a better society.

Display Week is SID's main annual event. Display Week 2014 was held in the beautiful city of San Diego and, overall, it was a very successful conference. We had more than 6,000 attendees this year, which is about a $10 \%$ increase over last year. We saw attendance improvement in most of the separate areas of the event, including the seminars and short courses. Our technical symposium had an attendance improvement of $10 \%$. The symposium featured many very interesting papers on a wide range of topics, including OLEDs, LCDs, flexible displays, oxide TFTs, and more, and these hottopic sessions were especially well attended. Finally, our exhibitor booth sales were also better than last year and continue to reflect the optimism of a modestly recovering global economy.

Both the Display Industry Awards and the Best in Show Awards are an important part of Display Week. This year's Display Industry Award Gold winners were Samsung's 5.68-in. curved flexible AMOLED display, receiving the Display of the Year award; Universal Display Corporation's green phosphorescent universal PHOLED material, receiving the Display Component of the Year award; and LG Display's G Flex phone, with the Display Application of the Year award. The Silver winners were LG Display's 55-in. FHD curved OLED TV, Canatu Oy's Carbon NanoBud Film, and Google's Chromebook Pixel. The Best in Show winners, selected at Display Week from exhibitors on the show floor, were Nanosys for its highdynamic-range wide-color-gamut display experience and GroGlass for its AR-coated glass and acrylic in the small-exhibit category; AUO for its WQHD smartphone displays in the medium-exhibit category; and LG Display for its UD OLED TVs and BOE for its $8 \mathrm{~K} \times 4 \mathrm{~K}$ display in the large-exhibit category.

SID's I-Zone has continued to be popular as a place to experience prototypes first hand. In many cases, these are early versions of products based on technology discussed in the technical symposium and other Display Week events. This year's I-Zone committee gave the Best Prototype Award to Ostendo Technologies, which demonstrated a novel display device it calls a Quantum Photonic Imager (QPI).

This year's show featured our Special Networking Event aboard the USS Midway, an aircraft carrier from WWII. We plan on continuing the networking event next year, along with the President's Cocktail Reception before our International Awards Banquet, and three other networking receptions for our Investor's Conference, Business Conference, and Market Focus Conferences. SID intends to continue to offer a host of networking opportunities at Display Week events for many years to come.

I have set some aggressive goals for the 2 years of my presidency. These include increasing the society's individual and corporate memberships. The goal for individual membership growth is about $5 \%$ and for corporate memberships about $20 \%$.
President: A. Ghosh

President-Elect: Y. S. Kim

Regional VP, Americas: A. Bhowmik

Regional VP, Asia: B. Wang

Regional VP, Europe: P. Kathirgamanathan

Treasurer: H. Seetzen

Secretary: T. Tsujimura

Past President: B. Berkeley

Bangalore: T. Ruckmongathen

Bay Area: J. Pollack

Beijing: X. Yan

Belarus: A. Smirnov

Canada: J. Vieth

Greater Dayton: D. G. Hopper

Delaware Valley: J. W. Parker II

Metropolitan Detroit: J. Kanicki

France: F. Templier

Hong Kong: H. S. Kwok

India: S. Sambandan

Israel: G. Golan

Japan: K. Kondoh

Korea: K.-W. Whang

Latin America: A. Mammana

Los Angeles: L. Tannas

Mid-Atlantic: J. Kymissis

Mid-Europe: H. De Smet

New England: S. Atwood

Pacific Northwest: A. Abileah

Russia: V. Belyaev

Singapore: T. Wong

Southwest: S. O'Rourke

Taipei: J. Chen

Texas: Z. Yaniv

U.K. \& Ireland: S. Day

Ukraine: V.Sergan

Upper Mid-West: B. Bahadur

\section{COMMITTEE CHAIRS}

Academic: P. Bos

Archives: L. Tannas, Jr.

Audit: S. O'Rourke

Bylaws: A. Silzars

Chapter Formation - Europe: H. De Smet

Conventions: P. Drzaic

Conventions Vice-Chair, BC and MC: J. Jacobs

Conventions Vice-Chair, Europe: I. Sage

Conventions Vice-Chair, Asia: K.-W. Whang

Definitions \& Standards: T. Fiske

Display Industry Awards: W. Chen

Honors \& Awards: F. Luo

I-Zone: B. Schowengerdt

Investment: $\mathrm{H}$. Seetzen

Long-Range Planning: Y. S. Kim

Membership: H.-S. Kwok

Membership Vice-Chair, Social Media: H. Atkuri

Nominating: B. Berkeley

Publications: H. Seetzen

Senior Member Grade: Y. S. Kim

Web Site: H. Seetzen

\section{CHAPTER CHAIRS}

Bangalore: S. Sambadam

Bay Area: R. Rao

Beijing: N. Xu

Belarus: V. A. Vyssotski

Canada: A. Kitai

Dayton: J. Luu

Delaware Valley: J. Blake

Detroit: J. Byrd

France: L. Vignau

Hong Kong: M. Wong

India: S. Kaura

Israel: I. Ben David

Japan: K. Kondo

Korea: S. T. Shin

Latin America: V. Mammana

Los Angeles: L. Iboshi

Mid-Atlantic: G. Melnik

Mid-Europe: H. J. Lemp

New England: J. Gandhi

Pacific Northwest: K. Yugawa

Russia: M. Sychov

Singapore/Malaysia: C. C. Chao

Southwest: M. Strnad

Taipei: C. C. Wu

Texas: R. Fink

U.K. \& Ireland: M. Jones

Ukraine: V. Sorokin

Upper Mid-West: R. D. Polak

SOCIETY FOR INFORMATION DISPLAY

1475 S. Bascom Ave., Ste. 114, Campbell, CA 95008 408/879-3901 e-mail: office@sid.org http://www.sid.org 


\section{continued from page 4}

We are expecting to increase attendance for all SID conferences by at least $10 \%$ over the next 2 years. Since the display industry has a large presence in Asia, a major goal is to reach out and expand our activities in that region. Our primary focus will be in China, where the display industry has seen very rapid growth over a short period of time. SID would like to participate and contribute toward this growth in China. More SID-sponsored conferences and the introduction of educational programs are some of our initial strategies.

In any society such as ours, publications play a crucial role. Our Journal of SID and Information Display magazine are the two key periodic publications, while our Symposium Digest and technical books play significant roles as well. John Wiley and Sons is our primary publisher, and this partnership is vital to the progress of our publications. Our goal for the next few years will be to improve and expand the quality and quantity of these publications which, in turn, should vastly improve the society's impact factor.

Lastly, the society's governance structure is more than 50 years old and needs an overhaul. The executive committee is in the process of strategizing a new structure that will not only be more efficient but will also allow for a more streamlined administration.

I would like to take this opportunity to thank our outgoing President, Brian Berkeley, and the entire SID leadership team for doing an outstanding job of turning around the financial health of the society. Just a few years ago, due to various unforeseen worldwide issues, including the SARS virus and economic downturns, the society's very existence was in question. Under Brian's leadership, the society has made a comeback and is once again doing well financially.

By the time you read this, SID and the Korea Information Display Society will have held the IMID 2014 conference in Daegu, Korea, in the last week of August. (This took place in conjunction with the SID board meeting.) The other major event of this year will be IDW (the International Display Workshops) in Niigata, Japan, to be held in December. I hope many of you will be able to attend this conference.

Finally, I hope you had an enjoyable summer vacationing with family and friends. We look forward to an exciting and productive fall season.

\section{Display Week 2015}

\section{SID International Symposium, Seminar \& Exhibition}

May 31-June 5, 2015

\author{
San Jose Convention Center \\ San Jose, California, USA
}

\section{Rolling Out the Red Carpet}

\section{I-Zone}

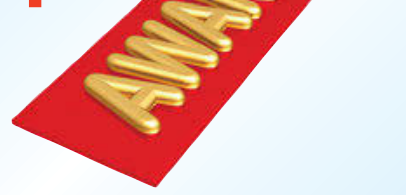

Competition of live demonstrations regarding emerging information-display technologies, such as not-yetcommercialized prototypes and proof of concepts.

\section{Individual Honors and Awards}

The SID Board of Directors, based on recommendations made by the Honors \& Awards Committee, grants several annual awards based upon outstanding achievements and significant contributions.

\section{Display Industry Awards}

Each year, the SID awards Gold and Silver Display of the Year Awards in three categories: Display of the Year, Display Application of the Year, and Display Component of the Year.

\section{Best in Show Awards}

The Society for Information Display highlights the most significant new products and technologies shown on the exhibit floor during Display Week.

\section{Journal of the Society for Information Display (USID) Outstanding Student Paper of the Year Award}

Each year a sub-committee of the Editorial Board of JSID selects one paper for this award which consists of a plaque and a $\$ 2000$ prize. 